\title{
A Microscopic Approach to Investigate Bacteria under In-Situ Conditions in Arctic Lake Ice: Initial Comparisons to Sea Ice
}

\author{
Karen Junge \& Jody W. Deming \\ School of Oceanography, Astrobiology Program, University of \\ Washington, Mail-box 357940, Seattle, WA 98195, U.S.A. \\ Hajo Eicken \\ Geophysical Institute, University of Alaska Fairbanks, 903 Koyukuk Dr., \\ P.O. Box 757320, Fairbanks, AK 99775-7320, U.S.A.
}

\begin{abstract}
To better understand constraints on bacteria at extremely low temperatures in ice, we describe here the adaptation of methods previously developed for sea ice to high magnification imaging of bacteria within fluid inclusions of Arctic lake ice under insitu conditions. Bacterial staining procedures, using the DNA-specific fluorescent stain DAPI, epifluorescence microscopy and image analysis were applied to lake-ice sections at in situ temperature $\left(-5^{\circ} \mathrm{C}\right)$. Abundances of total, attached, free-living and metabolically active lake-ice bacteria were also determined from samples melted at $0^{\circ} \mathrm{C}$ using the fluorescent stains DAPI and CTC. Initial results indicate that, compared to sea ice at the same in situ temperature, lake ice contains fewer and more isolated liquid inclusions, limiting transport of fluids and motion of bacteria. Metabolically active cells were found in all ice samples ( 0.1 to $2.0 \%$ of the total counts), but on average less than in sea ice. Up to $50 \%$ of the total bacterial community were found to be associated with particles $>3 \mu \mathrm{m}$ in size; of the metabolically active cells, a smaller fraction may be attached than in sea ice. Our results expand the spectrum of information available on bacteria in ice on a scale relevant to the organism and provide insight into characteristics of frozen microbial habitats on Earth and perhaps elsewhere in the Universe.
\end{abstract}

\section{Introduction}

Understanding constraints on microbial populations in extreme environments is of great interest in the context of Earth analogs for possible extraterrestrial habitats. Liquid or frozen water environments, such as Antarctic Lakes (Priscu et al. 1999; Karl et al. 1999), snow (Carpenter, Senjie \& Capone 2000) or permafrost soils (Rivkina et al. 2000), where microorganisms experience very low temperatures, are now being investigated as analogs of environments on Mars or the Jovian moon Europa. 
Based mostly on bulk measurements from melted ice samples, microbial communities have been found to exist and possibly even maintain their activity in these habitats on Earth, but the actual distribution and activity of the organisms under insitu conditions has not been demonstrated due to the lack of adequate technologies. Melting destroys the micro-environments within the ice matrix and precludes examination of microbial populations at spatial scales relevant to the organism. Previously, we examined wintertime Arctic sea ice, with minimum temperatures around $-20^{\circ} \mathrm{C}$, as another potential analog. Newly developed methods, both non-destructive (direct microscopic visualization of bacteria within the 3-D network of brine inclusions) and destructive (analysis of samples melted under near isothermal-isohaline conditions of the brine inclusions; i.e. ice melted in a brine solution to achieve near-constant in situ temperature and salinity and thus avoid thermal or osmotic shock to organisms living within the brine inclusions) were used with the objective to better understand constraints on bacterial communities at extremely low temperatures and high salinities (Junge et al. 2001a; Junge, Eicken, \& Deming 2001b, 2003). We demonstrated that life at sub-zero temperatures in sea ice depends upon the evolution of the morphology and distribution of the brine inclusions themselves and that the association of bacteria with surfaces is important for sustained activity at subzero temperatures (Junge et al. 2001a; Junge, Eicken, \& Deming $2001 \mathrm{~b}, 2003$ ). Do these findings apply only to sea ice or are they also valid for other microbial ice habitats on Earth?

Lake ice, the habitat predominantly studied to date as a proxy for extraterrestrial life (Priscu et al. 1999; Karl et al. 1999; Price 2000), differs from sea ice in its growth characteristics and reduced impurity concentrations (Eicken 2003). We thus expected liquid inclusions in lake ice to be more constricted spatially, less well connected and to harbor bacteria mainly associated with surfaces. To test these expectations, we adapted our sea-ice methods to high magnification imaging of bacteria within the fluid inclusions of Arctic lake ice at subzero temperatures.

Few assessments of bacterial abundance, activity and diversity in permanently cold lakes exist, e.g., in Alpine (Pernthaler et al. 1998), Antarctic (Ward \& Priscu 1997; Simmons, Vestal, \& Wharton 1999) or Arctic lakes (Bahr, Hobbie, \& Sogin 1996; Panzenboeck et al. 2000). Even fewer studies exist on bacterial communities the ice covering these lakes (Priscu et al. 1998, 1999; Karl et al. 1999; Gordon, Priscu, \& Giovannoni 2000; Christner et al. 2001). To our knowledge, Arctic lake-ice bacteria have not been studied so far. Here we briefly describe the method that allowed for the first microscopic observation of bacteria within frozen lake ice sections at in situ temperature $\left(-5^{\circ} \mathrm{C}\right)$ and present the first results of abundance and activity of Arctic lake-ice bacteria.

\section{Material and Methods}

Procedures for direct microscopic observation of bacteria in Arctic lake-ice sections closely followed the protocol for in-situ investigation of sea-ice samples described by Junge et al. (2001a). Briefly, lake-ice samples of an insitu temperature of $-5^{\circ} \mathrm{C}$ were collected using a $10-\mathrm{cm}$ diameter ice auger during November 2001 from two lakes in Alaska: Imikpuk Lake, a tundra lake of approximately 
0.5-km diameter and at maximum 3-4 m depth located near Pt. Barrow; and Ballaine Lake, a boreal forest lake of approximately 300-m diameter and a few meters depth located in Fairbanks. Storage and most sample processing, including staining and microscopic observations, occurred at $-5^{\circ} \mathrm{C}$ in a cold room (at the University of Alaska, Fairbanks), which accommodated the microscope and image-acquisition system. Processing started with the preparation of thin sections, including sawing and microtoming, performed at $-15^{\circ} \mathrm{C}$. After preparation, the ice sections were equilibrated to $-5^{\circ} \mathrm{C}$ for $2 \mathrm{~h}$ and a solution of the DNA-specific fluorescent stain 4', 6'-diamidino-2-phenylindole 2HCl (DAPI; $20 \mu \mathrm{g} \mathrm{ml}^{-1}$ in brine prepared from Instant Ocean, equilibrated to $-5^{\circ} \mathrm{C}$ for a minimum of $2 \mathrm{~d}$; see Junge et al. (2001a), for more detail) was added to the microtomed surface. The stain was allowed to diffuse into the sample for at least an hour and up to $24 \mathrm{~h}$ in the dark before microscopic examination. Ice sections examined microscopically included: a) Imikpuk Lake ice at a depth of $35 \mathrm{~cm}$ (Fig. 1A); b) Ballaine Lake ice, at 8-cm depth (Fig. 1B); and c) artificial freshwater ice containing cells of Planococcus mcmeekenii (Junge et al. 1998). The artificial ice was prepared from sterile PCR-grade distilled water and a 1:10 (vol:vol) inoculum of cells in late logarithmic phase of growth. Prior to inoculation, cells were prestained with $3 \mu \mathrm{g} \mathrm{ml}^{-1} \mathrm{DAPI}$, then inoculated and frozen at $-5^{\circ} \mathrm{C}$ (Fig. 1C).

Ice melts for bacterial enumeration were prepared from Imikpuk Lake ice (from 0 to $45 \mathrm{~cm} \mathrm{depth)} \mathrm{and} \mathrm{underlying} \mathrm{water} \mathrm{samples} \mathrm{using} \mathrm{standard} \mathrm{nucleo-}$ pore filtration and staining techniques (Porter \& Feig 1980; Junge et al. 2002). Care was taken to maintain sterile conditions throughout the process (e.g. by using autoclaved sawing and microtome blades). Ice samples were melted at $1-2^{\circ} \mathrm{C}$ within $72 \mathrm{~h}$ with and without $30 \% \mathrm{v} / \mathrm{v}$ formaldehyde that was added to the ice before melting. Two "killed samples", with a final concentration of $2 \%$ formaldehyde in the ice melts, came from depths of 25 and $40 \mathrm{~cm}$ in the ice cover and were used for total count determinations. Counts were scaled to the original volume of unmelted ice. Two 'live samples', melted without formaldehyde, came from 5- and 22-cm depths and were used for total and active count determinations. From each melt, triplicate $20-\mathrm{ml}$ subsamples were taken to determine the concentrations of total (killed and live samples) and metabolically active bacteria (live samples) using DAPI $\left(3 \mu \mathrm{g} \mathrm{ml}{ }^{-1}\right)$ and the fluorescent ETS-specific reagent 5-cyano-2, 3-ditoyl tetrazolium chloride (CTC; Sherr, del Giorgio, \& Sherr 1999), respectively. CTC was used at a final concentration of $5 \mathrm{mM}$ in 3 -h incubations at $1^{\circ} \mathrm{C}$ to determine concentrations of actively respiring cells for total, free-living and attached lake-ice bacteria, essentially as described in Junge et al. (2002). Abundances of free-living bacteria were determined from samples obtained by gentle filtration through a $3-\mu \mathrm{m}$ filter. Attached bacteria, defined as those retained in the $>3-\mu \mathrm{m}$ fraction, were calculated as the total count minus the free-living bacteria. To account for false positives, formalin-killed controls were prepared and incubated along with the live samples. After incubation, samples were preserved with formaldehyde ( $2 \%$ final concentration) and stored at $-20^{\circ} \mathrm{C}$ until slide processing and counting, which proceeded as described in Junge et al. (2002). In the formalin-killed controls, no CTC-positive cell was found. 


\section{Results and Discussion}

In applying methods originally developed for the microscopic examination of sea-ice samples to freshwater ice, we found that the use of DAPI in temperatureequilibrated brine solutions also allowed for successful detection of bacteria within fluid inclusions of lake-ice matrices at subzero temperatures. As in wintertime sea ice (Junge et al. 2001a), bacteria were clearly observed but often in tight clusters along fluid veins and in triple junctures (Fig. 1A-C).

Images obtained by these non-destructive methods also indicate that lake ice contains fewer and more constricted liquid inclusions than sea ice at the same temperature (compare Fig. 1A-C with Fig. 2 from Junge et al. (2001a) and Junge, Eicken, \& Deming 2001b, 2003), as expected based on the absolute impurity content of the parent waters of between 0.1 and 0.5 . Fewer and narrower liquid inclusions imply reduced exchange between liquid inclusions and spatial restrictions for bacteria to move into favorable locations. Furthermore, these initial observations showed that fluid inclusions differed in size and shape between the two lakes (with larger ones in the Ballaine Lake ice; compare Fig. $1 \mathrm{~A}$ with $1 \mathrm{~B}$, upper panels), suggesting that site-specific inorganic and organic chemical constituents of the parent water are important determinants of the micro-physical and chemical characteristics of the freshwater-ice habitat. More intensive study is needed to verify these initial observations and quantify the microstructural differences between sea and lake ice and among different lakes. Such comparisons can be expected to aid in identifying the general spectrum of micro-physical constraints experienced by bacterial communities inhabiting the various ice matrices on Earth and thus provide guidance as frozen environments elsewhere are considered for their possible habitability.

In the absence of an inorganic or organic chemical characterization of the parent lake waters and the segregation or partitioning of individual chemical species upon freezing, we opted to prepare the DAPI stain (required to visualize the bacteria) in a solution of sea salts. Although applying a drop of this staining solution onto the surface of the lake ice could have resulted in fluid flow in the upper ice (and thus in altered positions of unattached bacteria therein), we did not observe any changes in the size and shape of fluid inclusions or any movement of particles within the veins when images taken before and after application of the staining solution were compared. Since the briny staining solution was at thermal equilibrium with freshwater ice, no melting or ice crystal formation could occur. For the purposes of locating and enumerating bacteria within lake ice and relating microbial characteristics to the micro-physical environment, the method described here is very useful. For microscopic studies of the in-situ behavior or metabolic activities of individual bacteria within freshwater ice, however, staining solutions with chemical compositions closely resembling that of the brine inclusions within the ice veins to be examined should be developed.

Using the ice-melting approach for killed samples, we were able to quantify and compare bacterial abundances between lake ice and underlying water samples. Total bacterial abundance for Imikpuk Lake ice ranged from 0.41 to $1.6 \times 10^{6} \mathrm{ml}^{-1}$ for a mean of $1.3 \pm 0.49 \times 10^{6} \mathrm{ml}^{-1}$ ice compared to $2.6 \pm 0.66 \times 10^{6}$ $\mathrm{ml}^{-1}$ in lake water. The densities observed in the water samples were significantly higher than in the melted ice samples $(P=0.049)$, as assessed by a single factor parametric analysis of variance. These results fall within the range of published 

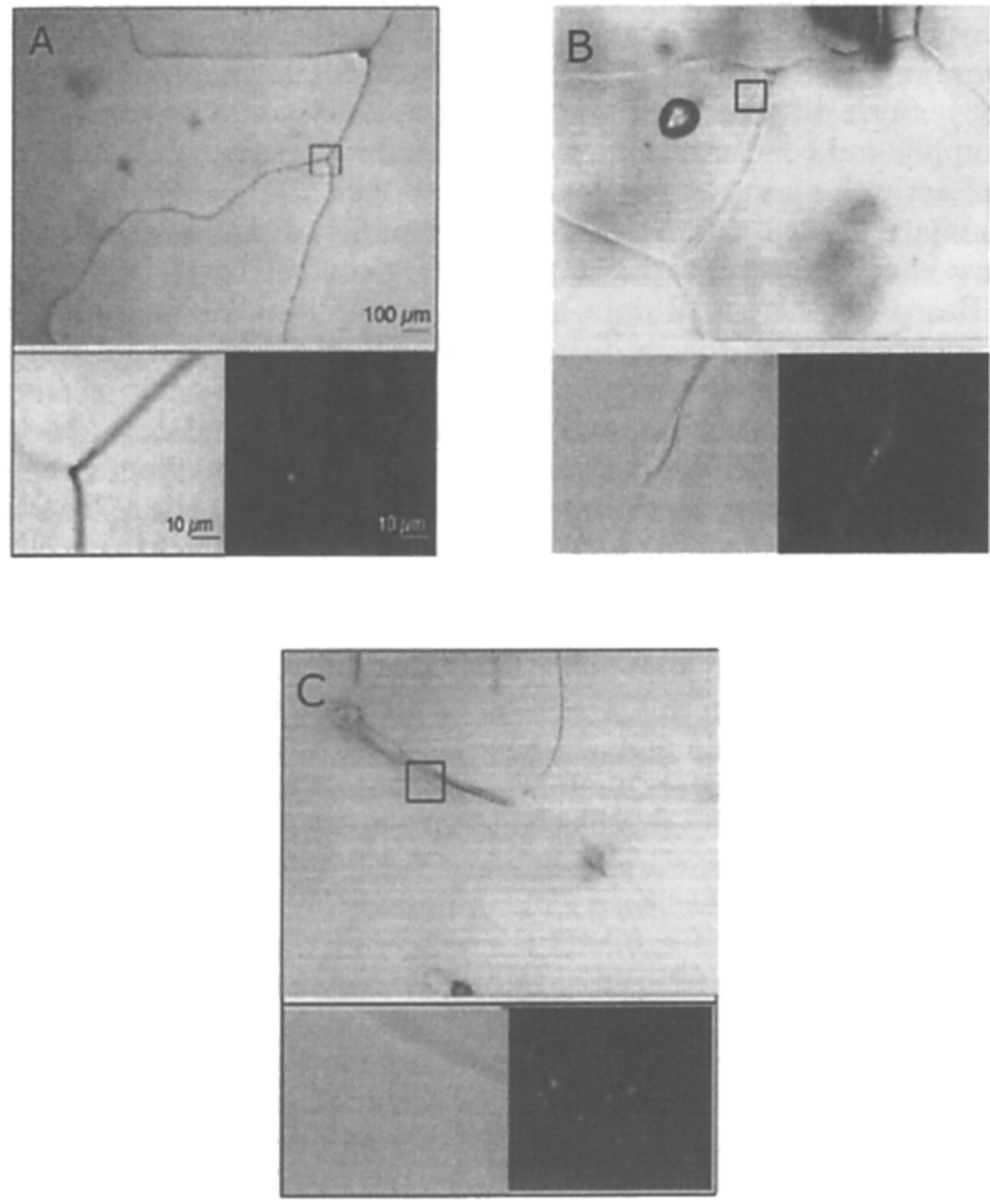

Figure 1. Microscopic images of lake ice from Imikpuk Lake (A) and Ballaine Lake (B) near Barrow and Fairbanks, Alaska, and of artificial ice prepared with pre-stained bacterial cells (C), all at $-5^{\circ} \mathrm{C}$. The upper panels show low-magnification transmitted light images, with small boxes referring to the high-magnification images under transmitted light (left) and corresponding epifluorescent light (right) in the lower panels. Transmitted light images reveal fluid inclusions and icegrain boundaries, often at triple junctures; epifluorescent images reveal DAPI-stained (blue) bacteria. 
values for permanently cold Arctic lake waters $\left(0.01\right.$ to $8 \times 10^{6} \mathrm{ml}^{-1}$; Panzenboeck et al. 2000), but are higher than what has been reported for Alpine lake water (1.1 to $6.6 \times 10^{5} \mathrm{ml}^{-1}$; Pernthaler et al. 1998) or Antarctic lake ice (0.08 to $3.6 \times 10^{4} \mathrm{ml}^{-1}$; Karl et al. 1999; Priscu et al. 1999), even though the in situ temperature at the time of sampling of the Arctic lake ice $\left(-5^{\circ} \mathrm{C}\right)$ was lower than those reported for Alpine and many Antarctic lakes $\left(0^{\circ} \mathrm{C}\right.$; Psenner \& Sattler 1998). Such differences in bacterial abundance could be due to differences in the supply and concentration of organic and inorganic nutrients available for bacterial activity and growth (Pomeroy \& Wiebe 2001). More extensive measurements are needed to make rigorous comparisons among the different lakes and draw conclusions as to what parameters control bacterial abundances in them. Based on this small data set, one of our initial hypotheses (i.e., that bacteria accumulate in the ice just as other dissolved impurities would with a distinct dependence on freezing rate and the concentration in the underlying liquid) could not be verified, since comparatively high numbers of bacteria were found within the ice. This result suggests a potential direct interaction between bacteria and ice surfaces possibly leading to differences in the segregation, such that a decrease in the freezing rate actually leads to an increase in cell numbers in the ice. Comparative studies of lakes in Antarctica that experience slower growth rates could aid in validating this hypothesis.

Using the ice-melting approach with live samples, bacteria metabolically active (CTC-stained or respiratory active cells) at $1^{\circ} \mathrm{C}$ were found in all of the ice melts examined. Their abundance ranged from 1.0 to $7.2 \times 10^{2}$ bacteria ml ${ }^{-1}$ or from 0.5 to $2.0 \%$ of the total count. These results allow a first assessment of actively respiring bacteria by this method in permanently cold lake ice. Typically, CTC-staining bacteria in warmer or more temperate lake waters have ranged from 8 to $47 \%$ of the total bacterioplankton assemblage (Haglund et al. 2002); including marine habitats expands the range on the lower end (0.4 to $47 \%$ ). CTC-stained bacteria have been suggested to represent those characterized by high levels of metabolic activity (Sherr, del Giorgio, \& Sherr 1999) and likely responsible for the bulk of bacterial community metabolic activity (Smith 1998). Based on our data collected so far, sea-ice bacterial assemblages are more active than those in lake ice: consistently higher percentages of CTC-stained bacteria were observed in springtime sea-ice samples (up to 27\%; Junge et al. 2002) and even in much colder wintertime sea-ice samples (up to 4\%; Junge, Eicken, \& Deming 2001b, 2003). Further studies are required to verify these findings, but they suggest that, in addition to potential differences in the concentration of organic nutrients, the presence of more habitable space and greater potential for fluid flow and bacterial movement within the sea-ice matrix compared to lake ice may provide clues to the observed differences in the fraction of the bacterial population that is metabolically active.

In comparing bacterial abundances between live and killed ice-melt samples, we found that in live samples (ice melted without prior addition of formaldehyde) the total bacterial counts represented only about $5 \%$ of those determined in killed samples $\left(7.0 \pm 3.7 \times 10^{4} \mathrm{ml}^{-1}\right.$ ice versus $1.3 \pm 0.49 \times 10^{6} \mathrm{ml}^{-1}$ ice $)$. This marked difference could conceivably reflect a very high spatial variability within the ice column, but more likely indicates the lysis of a significant number of cells during the melting process. Cells present in fluid inclusions of high ionic strength could experience osmotic shock when suddenly exposed to freshwater during 
melting, similar to the effect observed for sea-ice microorganisms upon direct melting of the ice (Garrison \& Buck 1986). The presence of the formaldehyde in the melt waters would have functioned as a cell-stabilizing agent by crosslinking membrane proteins and thereby preventing the cell from bursting. For accurate assessments of total bacterial abundance in lake ice, melting the ice into a fixative-containing solution (or adopting an isohaline melting approach) may be essential. Prior studies assessing only live melts may have severely underestimated the resident bacterial population (Priscu et al. 1999).

Attachment to particles and other surfaces is a well-known microbial strategy for surviving a variety of extreme conditions in aquatic systems, but studies of ice from this perspective have not yet been reported. We recently demonstrated that surfaces in wintertime sea ice are important for sustained activity at very low temperatures $\left(-20^{\circ} \mathrm{C}\right)$ with approximately half of all cells (active or not) appearing in the $>3-\mu \mathrm{m}$ size fraction and virtually $100 \%$ of the active cells being particle-associated (Junge, Eicken, \& Deming 2001b, 2003). Our preliminary findings on this subject from two lake-ice melts show that 52 and $27 \%$ of the total cells were attached to particles, in keeping with our earlier sea-ice results, but that smaller fractions ( 75 and $3 \%$ ) of the active cells may have been particle-associated.

Variables other than particulate surfaces may be more important for bacterial activity in subzero lake ice than in sea ice, but this inference awaits further study. Based on our in situ microscopic observations within the ice matrix for the same type of grain structure, most cells in lake ice may unavoidably associate directly with the surface of ice due to spatial restrictions within the narrow veins; what might control bacterial activity at the ice-fluid boundary has yet to be determined (Deming 2002). We suggest that in-depth comparative studies of wintertime sea ice and lake ice will provide further insights to understanding the mechanisms that control ice-bacterial activities at subzero temperatures and help guide the search for life elsewhere in the Universe, including but not limited to the polar ice caps of Mars and the icy surface layers of Europa (Chyba \& Phyllips 2001).

Acknowledgments. This research was supported by awards from the NSF LExEn program to J. W. Deming and H. Eicken and the NASA ABI and UW Astrobiology Program to J. W. Deming. We would like to thank undergraduate assistant M. Tapp for preparing the ice sections for microscopy and for helping throughout the course of this project.

\section{References}

Bahr, M., Hobbie, J. E., \& Sogin, M. L. 1996, Aquat. Microb. Ecol., 11, 271 Carpenter, E. J., Senjie, L., \& Capone, D. G. 2000, Appl. Environ. Microbiol., 66,4514

Christner, B. R., Mosley-Thompson, E., Thompson, L. G., \& Reeve, J. N. 2001, Environ. Microbiol, 3, 570

Chyba, C. F., \& Phillips, C. B. 2001, Proc. Natl. Acad. Sci. U.S.A., 98, 801

Deming, J. W. 2002, Curr Opin Microbiol, 5, 301 
Eicken, H. 2003, in Sea Ice - Its Physics, Chemistry, Biology and Geology, ed.

D. Thomas \& G. Dieckmann, (London: Blackwell Scientific), 22

Garrison, D. L., \& Buck, K. R. 1986, Pol. Biol., 6, 237

Gordon, D. A., Priscu, J., \& Giovannoni, S. 2000, Microb. Ecol., 39, 197

Haglund, A. L., Törnblom, E., Boström, B., \& Tranvik L. 2002, Microb. Ecol., 43,232

Junge, K., Gosink, J. J., Hoppe, H.-G., \& Staley, J. T. 1998, Syst. Appl. Microbiol., 21, 306

Junge, K., Krembs, C., Deming, J. W., Stierle, A., \& Eicken, H. 2001a, Ann. Glaciol., 33, 304

Junge, K., Eicken, H., \& Deming, J. W. 2001b, in Abstracts of the 101th General Meeting of the American Society for Microbiology, Washington, DC. at the American Society for Microbiology Annual Meeting, Orlando, FL. $\mathrm{N}-201,524$

Junge, K., Imhoff, J.F., Staley, J. T., \& Deming, J.W. 2002, Microb. Ecol., 43, 315

Junge, K., Eicken, H., \& Deming, J. W. 2003, submitted to Appl. Environ. Microbiol., in press

Karl, D. M., Bird, D. F., Bjoekman, K., Houlihan, T., Shackelford, R., \& Tupas, L. 1999, Science, 286,2144

Panzenboeck, M., Moebes-Hansen, B., Albert, R., \& Herndl, G. J. 2000, Aquat. Microb. Ecol., 21, 265

Pernthaler, J., Glockner, F. O., Unterholzner, S., Alfreider, A., Psenner, R., \& Amann, R. 1998, Appl. Environ. Microbiol., 64, 4299

Pomeroy, L. R., \& Wiebe, W. J. 2001, Aquat. Microb. Ecol., 23, 187

Porter, K. G., \& Feig, Y. S. 1980, Limnol. Oceanogr., 25, 943

Price, P. B. 2000, Proc. Natl. Acad. Sci. U.S.A., 97, 1247

Priscu, J. C., et al. 1998, Science, 280, 2095

Priscu J. C., et al. 1999, Science, 286, 2141

Psenner R., \& Sattler, B. 1998, Science, 280, 2073

Rivkina, E. M., Friedmann, E. I., McKay, C. P., \& Gilichinsky, D. A. 2000, Appl. Environ. Microbiol., 66, 3230

Sherr, B. F., del Giorgio, P., \& Sherr, E. B. 1999, Aquat. Microb. Ecol., 18, 117

Smith, E. M. 1998, Aquat. Microb. Ecol., 16, 27

Simmons, G. M., Vestal, J. R., \& Wharton, Jr., R. A. 1993, in Antarctic Microbiology, ed E. I. Friedmann, (New York: Wiley), 634

Ward, B. B., \& Priscu, J. C. 1997, Hydrobio., 347, 57 